\title{
The dragon learns to fly
}

C hina is quickly emerging from its isolation to fight for a leading role on the world stage. And as the Sleeping Giant awakens from its slumber, the rest of the globe has begun to pay attention. In the biomedical arena, the Chinese government seems to be firmly committed to investing in research and development, and institutions from every corner of the planet are vying to get closer to China, hoping to reap benefits from the sudden bonanza (page 264). But the scientific development of China is not set to be a smooth ride. As the country takes off, there are at least three fronts that will be fraught with difficulties and challenges for Chinese scientists: sustainability, accountability and credibility.

Sustainability. The research and development budget of the Chinese government has been steadily growing, enticing many Chinese expatriates to return to their country. But is the current rate of growth sustainable? And will the working conditions of the returning scientists match their expectations?

The situation in China is somewhat reminiscent of what for years has happened in Spain. Many bright aspiring researchers leave the country looking for better scientific perspectives. After their formative period, they try to return to Spain but find limited opportunities. The Spanish government then announces the creation of programs that will enable hundreds of researchers to return. But, when they arrive, what they find is far from ideal: limited lab space, funds and intellectual freedom - they are often little more than glorified postdocs. And when a different political party comes to power, the promises of support often vanish.

In China, the problem of volatility may not arise, owing to the monolithic structure of the country's political administration. But it is less certain whether those scientists who return will find conditions similar to what they experienced in US or European labs, and which would enable them to develop their full potential at home. Returning to the Spanish example, the most successful repatriation stories involve scientists who were already leaders abroad and returned home to head entire institutes that they could shape as they saw fit. China is already attracting high-profile scientists with a similar strategy. A key challenge for these new scientific leaders will be to ensure that they use their privileged positions to foster the careers of their junior colleagues and the sustainability of the government's investment.

Accountability. The Chinese government has been generous in its allocation of money for research, and it will naturally expect in return results that justify the investment. In this regard, China would benefit from looking carefully at the ordeal of South Korea.
The South Korean government bet heavily on stem cell research, unreservedly backing Woo-Suk Hwang while sending him an unambiguous message about the country's high expectations. China should learn from the experience of its neighbors that to expect quick breakthroughs in return for financial support, no matter how generous, is a dangerous business. Results matter, but not as much as high-quality, reliable science.

Another reading of the Hwang affair has been that the hierarchical organization of science in South Korea prevented whistleblowers from coming forward before the problems reached their terminal stage. China is no stranger to hierarchies, which could also impede transparency and accountability. In the US, hierarchies matter much less when it comes to research. People are trained to think critically and to voice their concerns. This freedom is central to the scientific success of this country and has arguably given it a competitive advantage over the rest of the world. So, if China wants to compete at this level, people in the higher echelons of the scientific enterprise must take a long, hard look at the hierarchical organization of their institutions. Highquality science seldom grows in the absence of an environment conducive to original thinking.

Credibility. Science, for all its objectivity, remains a human activity that reflects the best and worst of human nature. It is therefore not surprising that scientists working around the same biological question develop a strong sense of community that at times feels almost like a club. Any young scientist who has tried to become a prominent member of his or her community knows how difficult it is to break in. For Chinese scientists, breaking in may be even harder.

The case of Hui Zhen Sheng (page 265), who found it inexplicably difficult to get her work published in high-profile journals, is quite revealing in this regard. On the basis of episodes like this, not only Chinese, but also Latin American and other Asian scientists are quick to cry foul and to accuse journals and reviewers of discriminating against them. Even Japanese researchers, despite all their success, still feel like the poor cousin at the scientific banquet.

Conscious or unconscious discrimination may occasionally exist. But as unacceptable as the practice is, science is bound to reflect this aspect of human nature-wariness in the face of the unfamiliar. The challenge in this case is twofold. Chinese scientists must realize that recognition is never instantaneous and requires a lot of effort and involvement. The rest of the world, in turn, must abandon any existing prejudices against Chinese scientists, because one thing is for sure: we are going to hear a lot about them. 